$\begin{array}{ll}\text { Research Square } & \begin{array}{l}\text { Preprints are preliminary reports that have not undergone peer review. } \\ \text { They should not be considered conclusive, used to inform clinical practice, } \\ \text { or referenced by the media as validated information. }\end{array}\end{array}$

\title{
Assessment of the Effectiveness of Collective Decisions for Maintenance- Rehabilitation Works of Water Pipelines Using a Qualitative Risk-based Group Decision-Making Model
}

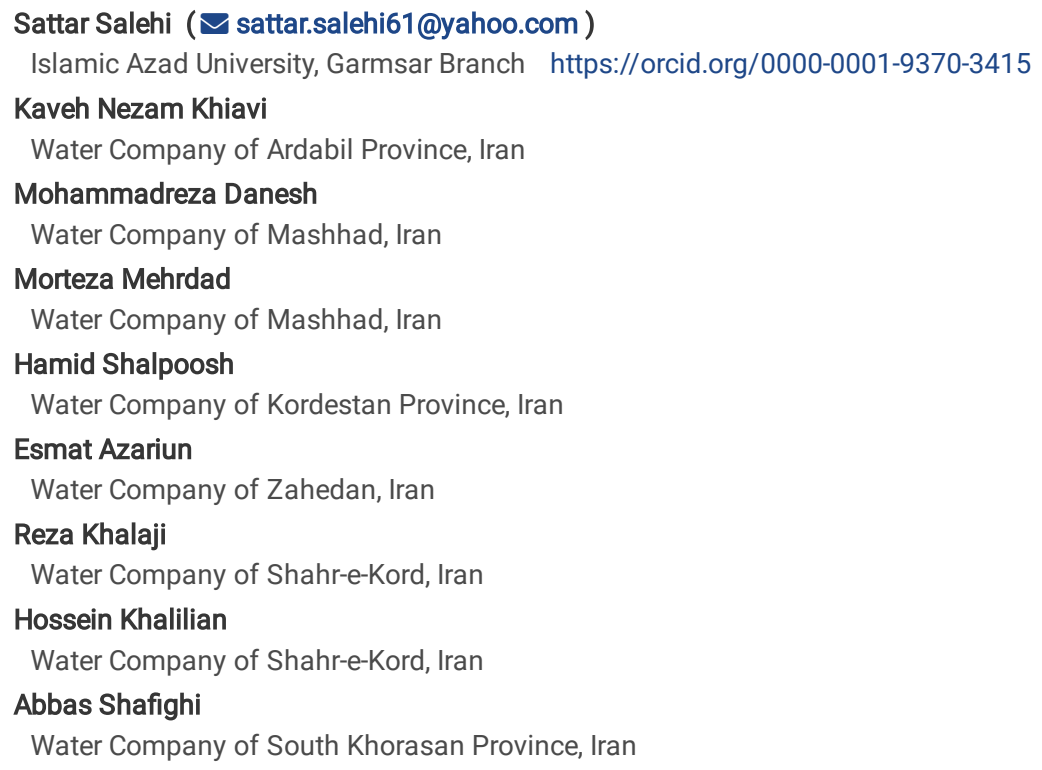

\section{Research Article}

Keywords: Water Pipeline, Maintenance-Rehabilitation Works, Collective Decision, Group Decision-Making, Qualitative Risk-based Method, Effectiveness Posted Date: January 17th, 2022

DOI: https://doi.org/10.21203/rs.3.rs-1009028/v1

License: @ (7) This work is licensed under a Creative Commons Attribution 4.0 International License. Read Full License 


\section{Abstract}

Among the most important decisions in water companies are planning the Maintenance-Rehabilitation Works (MRWs) of water pipelines. Since the MRWs are costly, it is essential to use the collective decisions of an expert team for planning these works. However, the effectiveness of these group decisions is not very clear and has been less considered in previous studies. Hence, the main objective of this research is to assess the effectiveness of these collective decisions. For this purpose, the MRWs of water pipes are determined based on two methods. In the first, the collective decision of experts is omitted, and in the second one, these decisions are considered. Finally, the results obtained from these methods are compared. The method used in this work for collective decisions is based on the nominal group technique. Furthermore, since there is deep uncertainty in water network data as well as hesitation in the group decisions, a qualitative (fuzzy) risk-based group decision-making model is developed in this research. The water pipelines studied in this work, as the case study, are addressed to pipes, which have been proposed by water companies in the six provinces of Iran. The MRWs of these pipes are determined, first, using the collective decision of 76 experts in these water companies; and then, without this group decision making. The results of comparing these methods indicated that group decisions do not have a significant effect on prioritizing water pipelines for the MRWs. While, in determining the renovation strategies of pipes, the viewpoints of experts could have a decisive effect on the results. Furthermore, it was found that increasing the number of decision criteria could lead to more realistic results; whereas, the number of assessed pipelines as well as the number of decision makers does not have an obvious effect on the results.

\section{Introduction}

Water Distribution Networks (WDNs) are among the main infrastructure in human societies; thus, the Maintenance-Rehabilitation Works (MRWs) of these networks have always been one of the most important concerns of water companies. Hence in the last decade, many studies have been conducted in regards to MRWs of water networks (Ramos et al. 2021, Dell'Aira et al. 2021, Vieira et al. 2020, Elshaboury et al. 2020a, Cabral et al. 2019, Salehi et al. 2019, Tscheikner-Gratl et al. 2016, Choi et al. 2015, Scholten et al. 2014, Salman et al. 2013, Tabesh and Saber 2012, Saldarriaga et al. 2010).

Hence, it is essential to consider an appropriate method for planning MRWs of water pipelines, so that, leading to improve the hydraulic-mechanical operation of these pipes. For this purpose, various methods have been developed since 2000. Some of these studies are focused to use multi-criteria Decision-Making Methods (DMMs) (GÜL and FIRAT 2020, Minaei et al. 2019, Salehi et al. 2018a, Lee et al. 2018, Tscheikner-Gratl et al. 2017, Rahmani et al. 2015, Scholten et al. 2014, Willuweit and O'Sullivan 2013, Carrico et al. 2012, Alvisi and Franchini 2009, 2006, Haidar and Le Gauffre 2004); whereas, in many other studies, the risk-based DMMs are mainly developed (Wéber et al. 2020, Salehi et al. 2020, Zhou et al. 2019, Phan et al. 2019, Lin and Yuan 2019, Barton et al. 2019, D'Ercole et al. 2018, Shortridge and Guikema 2014, Scheidegger et al. 2013, Devera 2013, Bicik 2010, Lindhe et al. 2009, Christodoulou et al. 2009, Rogers and Louis 2008, Giustolisi et al. 2006). Meanwhile, the deep uncertainty involved in WDN data has been considered in some of these risk-based methods (Salehi et al. 2020, Wang et al. 2019, Khameneh et al. 2019, Salehi et al. 2018a, Xie et al. 2017, Lee et al. 2000).

Dell'Aira et al. (2021) proposed a novel approach for a hybrid method of design-rehabilitation of WDNs. A new version of NSGA-II in combination with EPANET 2 software was developed in their studies to assess the ageing phenomena in WDNs. However, it seems that the uncertainty in WDN data was not considered in this study. Wu and Abdul-Nour (2020) presented the results of a study in which different multi-criteria group DMMs were investigated to select a sewer network design. In this research, four applied DMMs including AHP, TOPSIS, ELECTRE III and PROMETHEE II were assessed. Finally, the best results were obtained from PROMETHEE II and TOPSIS methods. However, this research focused on the design of municipal sewer networks and urban WDNs were not considered by researchers. Xiao Zhou et al. (2019) presented a new framework by Fully-linear DenseNet to identify the accurate burst locations in WDNs; so that, can be used for MRWs planning. However, proposing a prioritization plan for repairing the pipes was not considered in this research.

Tscheikner-Gratl et al. (2017) assessed five multi-criteria DMMs namely ELECTRE, AHP, WSM, TOPSIS and PROMETHEE to prioritize the rehabilitation of WDNs. The results of this study indicated that the output of these DMMs is not the same for renovation planning and each model can offer different programs. However, in this study, group and risk-based DMMs have not been studied. Fontana and Morais (2016) presented a model that can be used to plan preventive maintenance works of WDNs to reduce the volume of water loss. In this research, a combined DMM consisting of a multivariate value analysis model with the SMARTER method as well as linear programming has been used. However, in this research, prioritizing the maintenance works of pipes has not been considered by researchers.

Since the operation of WDNs is so complex, it is usually needed to use the collective viewpoints of a specialized team for decision-making of pipes' MRWs (Salehi et al. 2018a, Tabesh et al. 2020, Fontana and Morais 2017, Morais and Almeida 2010, Morais and de Almeida 2007). Accordingly, the DMM developed in this field would be better a group decision model. Over the last ten years, various studies have been conducted on group DMM related to water supply systems and water resources management.

In some of these studies, group decision-making was used in the field of reducing water losses in the WDNs (Tabesh et al. 2020, Morais and de Almeida 2007, Morais et al. 2014, Mutikanga et al. 2011); However, in other studies, group DMMs have been considered in the field of WDN management (Noori et al. 2020, Amorocho-Daza et al. 2019, Minatour et al. 2015, Haider et al. 2015, Roozbahani et al. 2012). Meanwhile, some studies of group DMMs in water networks are directly related to the network MRWs (Choi et al. 2015, Salehi et al. 2018a, Salehi et al. 2020, Bicik 2010, Fontana and Morais 2017, Morais and Almeida 2010, Elshaboury et al. 2020b, da Silva Monte et al. 2016, Trojan and Morais 2012).

Zolghadr-Asli et al. (2021) recently presented review research on studies conducted in the last 20 years, in which multi-attribute DMMs in the field of water resources management had been used. One of the factors considered in this research was the group decisions and the number of decision makers in various studies. The results of this study indicated that the use of multi-attribute DMMs for water resources management, especially in the Middle East, is increasing. In this study, it was found that methods such as the Delphi can be useful for multi-attribute group DMMS. However, in this study, the assessment of the effectiveness of group DMMs for planning the renovation of WDNs has not been considered. 
Elshaboury et al. (2020) presented a study to determine the weight of variables affecting the water pipe failures. In this study, the Fuzzy ANP multi-criteria DMM was used, and group DMM was also considered by researchers. The GEOmetric mean (GEO) and Minimum-Maximum (Min-Max) methods were used in this research to implement group decisions. The case study of this work was related to a network in a city in Egypt. However, in this study, only the results of several group DMMs in the assessment of the condition of the pipes have been investigated; thus, the effectiveness of these methods in planning the maintenance of WDNs has not been considered. Salehi et al. (2018) have been developed a model called the WDSR model, which was a multi-attribute group DMM based on the Fuzzy TOPSIS method. This model was developed only to prioritize pipes and areas of WDNs for planning network renovation. However, in this model, the assessment of the effectiveness of group DMMs in prioritizing pipes has not been considered.

da Silva Monte et al. (2016) presented the results of a study in which the techniques for determining the weight of different decision makers in group DMM was investigated. The field of this study was related to the maintenance of wells in WDNs, in which decision-makers consisted of 3 experts with different views. However, in this study, the maintenance of the water pipeline has not been considered and the viewpoints of a limited number of decision makers have been assessed. Choi et al. (2015) has assessed the condition of pipes in WDNs. Based on this research, they provided a method to maintain and repair the pipes in each zone of the network. Moreover, a group decision of 25 experts was used to weight different zones of the network based on their performance index; and the AHP method was applied to determine these weights. Finally, the ELECTRE method was used to prioritize network zones. However, in this study, the pipes prioritization for renovation was not considered and the effectiveness of group DMM was not assessed.

Given the most studies in the field of WDNs renovation, it is obvious that mainly the effectiveness of group DMMs used in this field has been less considered; while, these decisions could be useful for Maintenance-Rehabilitation Works (MRWs) of distribution networks. The efficiency of group DMMs has been recently considered in other fields (Hsieh et al. 2020); nevertheless, not has been used in the WDNs design and operation field.

The main objective of the present study is to assess the effectiveness of collective decisions in planning the MRWs of water pipelines. In this regard, the specific pipes proposed by the 6 water companies of Iran have been investigated; and then, using the viewpoints of 76 experts in these companies, the MRWs of the pipes were planned. Accordingly, the nominal group technique was used in this research for collective decision. In addition, to assess the effectiveness of group decisions a DMM has been developed in the present work; and then, the results of two methods including no-group DMM and group DMM were compared. Meanwhile, given the deep uncertainty involved in WDNs data (Scheidegger et al. 2013, Lee et al. 2000, Urich and Rauch 2014) as well as the hesitation in group decisions (Carneiro et al. 2021, Wu et al. 2020, Carneiro et al. 2019), a qualitative (fuzzy) risk-based approach was added to the developed model in this research.

The risk-based DMM developed in this research is a new version of the RC-WDSR model, which was introduced in 2020 (Salehi et al. 2020 ). However, as mentioned previously, in the model of the present work, the numerical analysis of risk (quantitative) has been omitted; and as a new approach, only qualitative risk-based decision-making was considered for planning MRWs of the water pipelines. This is because that the deep uncertainty in WNDs data and hesitation in group decisions could lead to more complex analysis in the quantitative risk-based methods. The results of this work indicate that the opinions of experts do not have a significant effect on pipe prioritization for MRWs. However, decision-makers' viewpoints can be effective and decisive in determining pipe renovation strategies.

\section{Material And Methods}

The main objective of this research is to assess the effectiveness of collective decisions for planning MRWs of the water pipelines in WDNs. For this purpose, a qualitative risk-based model was developed using a multi-criteria group DMM. Figure 1 illustrates the analytic steps of this model.

Figure 1 near here

As illustrated in Figure 1, the analytic steps of the developed model in this research are described separately below:

\subsection{Step 1. Determining the decision criteria}

To plan MRWs of the water pipelines in WDNs, identifying the effective variables in pipes prioritization is of great importance. Therefore, during the studies conducted in the previous years (Salehi et al. 2018a, Salehi et al. 2020), 42 and 48 criteria have been recognized as effective in determining the priority of pipe for rehabilitation. In the present study, the criteria affecting the priority of pipes for MRWs were developed to 50; and were divided into two categories of criteria and sub-criteria. Figure 2 shows the criteria and sub-criteria effective in the prioritization of pipe for MRWs.

\section{Figure 2 near here}

The model developed in this research is well-established, which can analyse any network with any number of criteria as well as any number of pipes. Furthermore, it is possible to assess network data with uncertainty using this model. Therefore, even networks with 1 or 2 criteria (accurate or imprecise) and with any number of pipes can be assessed by this model.

\subsection{Step 2. Selecting the case studies}

In this step, the case studies of research were selected. For this purpose, to consider a wide range of different regions of Iran, WDNs from the six provinces were chosen. Furthermore, for selecting these provinces, the various combinations of the numbers of decision makers/pipes/criteria were considered. Finally, a total of 76 decision-makers participated in these provinces. The dispersion of these six provinces and the numbers of decision makers/pipes/criteria in their water companies are shown in Figure 3.

Figure 3 near here 
The number of pipes studied in this work was proposed by each water company. In addition, the numbers of criteria were determined based on data available in water companies. In this work, the selection of decision makers was based on their knowledge and work experience and was completely voluntary. The educational degrees and work experiences of these decision makers are presented in Table 1 in percentage.

Table 1

The profile of decision-maker experts in this research

\begin{tabular}{|c|c|c|c|c|c|c|c|c|}
\hline \multirow[t]{2}{*}{ No. } & \multirow{2}{*}{$\begin{array}{l}\text { Water Company } \\
\text { of Province }\end{array}$} & \multirow{2}{*}{$\begin{array}{l}\text { Number of } \\
\text { Decision-Maker Experts }\end{array}$} & \multicolumn{3}{|l|}{ Education } & \multicolumn{3}{|c|}{ Work Experience } \\
\hline & & & Bachelor & Master & Ph.D & Year $<10$ & $10<$ Year $<20$ & Year 20 \\
\hline 1 & Ardabil & 9 & $44.44 \%$ & $44.44 \%$ & $11.11 \%$ & $11.11 \%$ & $44.44 \%$ & $44.44 \%$ \\
\hline 2 & Chaharmahal and Bakhtiari & 14 & $64.28 \%$ & $35.72 \%$ & $0 \%$ & $50 \%$ & $42.86 \%$ & $7.14 \%$ \\
\hline 3 & Kurdistan & 9 & $55.56 \%$ & $44.44 \%$ & $0 \%$ & $44.44 \%$ & $22.22 \%$ & $33.34 \%$ \\
\hline 4 & Razavi Khorasan & 23 & $43.48 \%$ & $47.83 \%$ & $8.69 \%$ & $34.78 \%$ & $43.48 \%$ & $21.74 \%$ \\
\hline 5 & Sistan and Baluchestan & 11 & $36.36 \%$ & $63.64 \%$ & $0 \%$ & $27.27 \%$ & $54.54 \%$ & $18.19 \%$ \\
\hline 6 & South Khorasan & 10 & $40 \%$ & $60 \%$ & $0 \%$ & $20 \%$ & $40 \%$ & $40 \%$ \\
\hline
\end{tabular}

\subsection{Step 3. Determining the qualitative risk of pipes}

In this study, to determine the pipe risk, the Pipe Failure Probability (PFP) and Pipe Failure Consequence (PFC) were assessed based on criteria determined in step 1. The method used for risk assessment in this research was based on analytic steps of the RC-WDSR model, which has been introduced in Salehi et al. (2020). For this purpose, in each case study, the conditions of the water pipelines were investigated in regards to 50 criteria. However, it should be noted that all criteria do not have the same role in pipe failure. Indeed, as shown in Table 2, some of these criteria are effective in PFP and others affect PFC. While, some of these criteria have a simultaneously influence on the probability and consequence of pipe failures (Table 2). The major information in Table 2 is obtained from Salehi et al. (2020). 
Table 2

The criteria effective on probability or consequence of pipe failure (Salehi et al. 2020)

\begin{tabular}{|c|c|}
\hline Criteria Effective on & Criteria Effective on \\
\hline Probability of Pipe Failure & Consequence of Pipe Failure \\
\hline Pipe Flow & Pipe Flow \\
\hline Pipe Flow Velocity & Pipe Average Pressure \\
\hline Pipe Average Pressure & Pipe Length \\
\hline Pipe Age & Pipe Diameter \\
\hline Pipe Length & Pipe Depth \\
\hline Pipe Diameter & Pipe Maintenance Ease \\
\hline Pipe Depth & Pipe Failure Rate \\
\hline Pipe Roughness & Pipe Leakage Rate \\
\hline Invulnerability of The Pipe in The Installation & Customers Complaints About The Water Quality \\
\hline Pipe Lifetime & Residual Chlorine of Water in The Pipe \\
\hline External Loading Capacity of Pipe & Water Age in the Pipe \\
\hline External/Internal Corrosion of Pipe & Soil Type/Bedding around the Pipe \\
\hline Non-Floatable Ability of Pipe & Excavation Ease of the Soil around the Pipe \\
\hline Heat Resistance of Pipe & Pathway Type in top of the Pipe \\
\hline Earthquake Resistance of Pipe & Pathway Cover in top of the Pipe \\
\hline Pipe Failure Rate & Pathway Cover Thickness in top of the Pipe \\
\hline Pipe Leakage Rate & Pipe Location in the Pathway \\
\hline Residual Chlorine of Water in The Pipe & Pathway Level in top of the Pipe \\
\hline Water Age in the Pipe & Customers Type of Pipe \\
\hline Soil Type/Bedding around the Pipe & Combination of Customers of Pipe \\
\hline Soil Corrosion around the Pipe & Number of Customers of Pipe \\
\hline Pathway Type in top of the Pipe & Customers Density of Pipe \\
\hline Pathway Cover in top of the Pipe & Pipe Customers' Building Age \\
\hline Pathway Cover Thickness in top of the Pipe & Number of Connections in the Pipe \\
\hline Pathway Traffic Load in top of the Pipe & Number of Junctions in the Pipe \\
\hline Pipe Location in the Pathway & Number of Control Valves in the Pipe \\
\hline Number of Connections in the Pipe & Number of Pressure Valves in the Pipe \\
\hline Number of Junctions in the Pipe & Number of Hydrants in the Pipe \\
\hline Number of Control Valves in the Pipe & Implementation/Installation Cost of Pipe \\
\hline Number of Pressure Valves in the Pipe & Operational Cost of Pipe \\
\hline Number of Hydrants in the Pipe & Renewal Cost of Pipe \\
\hline \multirow[t]{6}{*}{ Installation Quality of Pipe } & Return on Investment of the Pipe Renewal \\
\hline & Municipal/Social Importance of Pipe \\
\hline & Political/Security Importance of Pipe \\
\hline & Pipe Water Supply Importance to Customers \\
\hline & Pipe Importance in Respect To Other Urban Facilities \\
\hline & Pipe Importance in Urban Management Plans \\
\hline
\end{tabular}

Since there is deep uncertainty in the WDNs data and some numerical information of these networks are imprecise (Wang et al. 2019, Khameneh et al. 2019, Marques and Cunha 2020, Fletcher et al. 2017, Torres et al. 2009, Sadiq et al. 2008, Kapelan et al. 2004), quantitative risk analysis of pipe failure has been not considered in this study. Thus, the linguistic-fuzzy (qualitative) risk-based method was used to determine the condition of the pipes in relation to each criterion. Additionally, this method could be useful for collective decisions due to the hesitation in group decision-making (Wu et al. 2020, Tang et al. 2019, 
Madani et al. 2014, Vahdani et al. 2011, Jiang et al. 2011, Anisseh and Mohd Yusuff 2011). In this regard, to determine the pipe condition the form of Table 3 was generated.

Table 3

The form used in this research to determine the pipe qualitative risk

\begin{tabular}{|c|c|c|c|c|c|c|c|c|}
\hline \multicolumn{9}{|c|}{ Pipe Number ....... } \\
\hline \multicolumn{9}{|c|}{ Pipe Location (Address): } \\
\hline \multirow[t]{5}{*}{ No. } & \multirow[t]{5}{*}{ Sub-Criteria } & \multirow{2}{*}{\multicolumn{7}{|c|}{$\begin{array}{l}\text { Determination of the Qualitative Risk in respect to each Sub-Criterion } \\
\text { Using Linguistic/Fuzzy Values in relating to Pipe Condition }\end{array}$}} \\
\hline & & & & & & & & \\
\hline & & \multirow{2}{*}{ Very Low Risk } & Low & Relatively & \multirow[t]{2}{*}{ Medium Risk } & \multirow{2}{*}{$\begin{array}{l}\text { Relatively High } \\
\text { Risk }\end{array}$} & High & \multirow[t]{2}{*}{ Very High Risk } \\
\hline & & & Risk & Low Risk & & & Risk & \\
\hline & & $(0,0,1,2)$ & $(1,2,2,3)$ & $(2,3,4,5)$ & $(4,5,5,6)$ & $(5,6,7,8)$ & $(7,8,8,9)$ & $(8,9,10,10)$ \\
\hline 01 & Pipe Flow & $\begin{array}{l}\text { Very Low } \\
\text { Flow }\end{array}$ & Low Flow & $\begin{array}{l}\text { Relatively Low } \\
\text { Flow }\end{array}$ & Medium Flow & $\begin{array}{l}\text { Relatively High } \\
\text { Flow }\end{array}$ & High Flow & $\begin{array}{l}\text { Very High } \\
\text { Flow }\end{array}$ \\
\hline . & . & . & . & . & . & . & . & . \\
\hline . & . & . & . & . & . & . & . & . \\
\hline . & & . & . & . & . & . & . & . \\
\hline 50 & $\begin{array}{l}\text { Pipe Importance in } \\
\text { Urban Management } \\
\text { Plans }\end{array}$ & $\begin{array}{l}\text { Very Low } \\
\text { Importance of } \\
\text { Pipe }\end{array}$ & $\begin{array}{l}\text { Low } \\
\text { Importance } \\
\text { of Pipe }\end{array}$ & $\begin{array}{l}\text { Relatively Low } \\
\text { Importance of } \\
\text { Pipe }\end{array}$ & $\begin{array}{l}\text { Medium } \\
\text { Importance } \\
\text { of Pipe }\end{array}$ & $\begin{array}{l}\text { Relatively High } \\
\text { Importance of } \\
\text { Pipe }\end{array}$ & $\begin{array}{l}\text { High } \\
\text { Importance } \\
\text { of Pipe }\end{array}$ & $\begin{array}{l}\text { Very High } \\
\text { Importance of } \\
\text { Pipe }\end{array}$ \\
\hline
\end{tabular}

Table 3 near here

In this table, each criterion was divided into seven categories. This categorization was not based on numerical classification, but on linguistic-fuzzy division. The condition of each pipe in relation to each criterion was determined based on the available field data as well as the knowledge and experience of the network operator who filled the form (Table 3). The fuzzy numbers assigned to linguistic values were trapezoidal fuzzy numbers. A trapezoidal fuzzy value ( $\left.\tilde{\mathrm{x}}=\left(\mathrm{x}_{\min }, \mathrm{x}_{\mathrm{ave} 1}, \mathrm{x}_{\mathrm{ave} 2}, \mathrm{x}_{\max }\right)\right)$ is introduced as a four-component number, in which $\mathrm{x}_{\min }$ and $\mathrm{x}_{\max }$ indicate the minimum and maximum possible values, whereas, $\mathrm{x}_{\mathrm{ave} 1}$ and $\mathrm{x}_{\mathrm{ave} 2}$ show the most probable values for a given number. The characteristic function of this number follows in below (Anisseh and Mohd Yusuff 2011, Salehi et al. 2018b):

$\mu_{\tilde{A}}(\mathrm{x}) \mid \begin{gathered}0 x \leq \mathrm{x}_{\min } \\ \frac{\mathrm{x}-\mathrm{x}_{\min }}{\mathrm{x}_{\mathrm{ave} 1}-\mathrm{x}_{\min }} \mathrm{x}_{\min } \leq x \leq \mathrm{x}_{\mathrm{ave} 1} \\ 1 \mathrm{x}_{\mathrm{ave} 1} \leq x \leq \mathrm{x}_{\mathrm{ave} 2} \\ \frac{\mathrm{x}_{\max }-\mathrm{x}}{\mathrm{x}_{\max }-\mathrm{x}_{\mathrm{ave} 2}} \mathrm{x}_{\mathrm{ave} 2} \leq \mathrm{x} \leq \mathrm{x}_{\max } \\ 0 x \geq \mathrm{x}_{\max }\end{gathered}$

\subsection{Step 4. Planning the maintenance-rehabilitation works of pipes}

In this study, filling the form of the pipes' qualitative risk (Table 3) by the network operator, the priority and renovation strategy of pipes were determined. To analyse this form, a multi-criteria decision model was developed based on the TOPSIS method, which has been introduced firstly by Yoon and Hwang (1981). The reason for using this method is its significant ability in planning the design and rehabilitation of water and sewer networks (Salehi et al. 2018a, Tscheikner-Gratl et al. 2017, Wu and Abdul-Nour 2020); Whereas, the other methods (e.g. AHP) do not have the desired capability to analyse decision-making problems where the number of criteria and alternatives increase (Tscheikner-Gratl et al. 2017, Wu and Abdul-Nour 2020, RazaviToosi and Samani 2019, Islam et al. 2013, Yazdani et al. 2012). In addition, considering the fuzzy-linguistic values used in this research, the model developed in this research was based on Fuzzy TOPSIS.

Since the criteria considered in this research had different scales, in the first stage of the Fuzzy TOPSIS model, the fuzzy values related to the pipes' qualitative risk were changed to descaled fuzzy values based on the formula presented below:

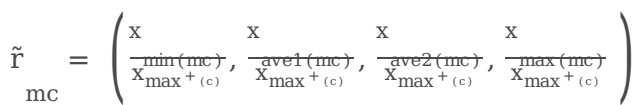


$\mathrm{x}_{\max }{ }^{+(\mathrm{c})}=\mathrm{m}^{\mathrm{Max}_{\mathrm{X}}}$

$\tilde{r} \quad$ : Descaled fuzzy value of the $\mathrm{m}^{\text {th }}$ water pipeline in related to $\mathrm{c}^{\text {th }}$ criteria

$\mathrm{mc}$

$m=1,2, \ldots, m, c=01,02, \ldots, 50$

Afterwards, two target and theoretical pipes which have the highest and least failure risk were calculated using the following formula:

Pipe with highest risk (the most critical pipe for maintenance-rehabilitation works) $=\mathrm{V}^{+}$

$\mathrm{V}^{+}=\left\{\tilde{\mathrm{v}}_{01}^{+}, \ldots \ldots \ldots, \tilde{\mathrm{v}}_{\mathrm{c}}^{+}\right\}, \tilde{\mathrm{v}}_{\mathrm{c}}^{+}=\operatorname{Max}_{\mathrm{m}}\{\tilde{\mathrm{r}} \underset{\mathrm{mc}}{ }\}(3)$

Pipe with least risk (the least important pipe for maintenance-rehabilitation works) $=\mathrm{V}^{-}$

$\mathrm{V}^{-}=\left\{\tilde{\mathrm{v}}_{01}^{-}, \ldots \ldots \ldots, \tilde{\mathrm{v}}_{\mathrm{c}}^{-}\right\}, \tilde{\mathrm{v}}_{\mathrm{c}}^{-}=\operatorname{Min}_{\mathrm{m}}\left\{\tilde{\mathrm{r}}_{\mathrm{mc}}\right\}(4)$

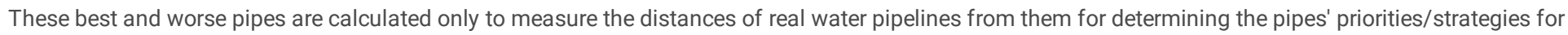
MRWs. Indeed, these pipes are theoretical and do not exist in real WDNs.

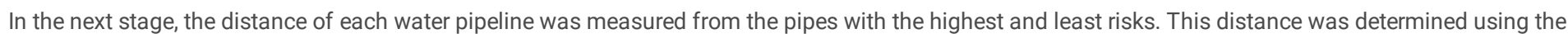
below formula:

Distance of water pipeline from the pipes with the highest/least risk $=\mathrm{S}_{\mathrm{m}}^{ \pm} \mathrm{S}_{\mathrm{m}}^{ \pm}=\sum_{\mathrm{c}=01}^{\mathrm{C}} \mathrm{d}\left(\tilde{\mathrm{v}}_{\mathrm{mc}}, \tilde{\mathrm{v}}_{\mathrm{C}}^{ \pm}\right)$

$=\sqrt{\frac{1}{4}\left[\left(\mathrm{v}_{\min (\mathrm{mc})}-\mathrm{v}_{\min (\mathrm{c})}^{ \pm}\right)^{2}+\left(\mathrm{v}_{\operatorname{ave1}(\mathrm{mc})}-\mathrm{v}_{\operatorname{ave} 1(\mathrm{c})}^{ \pm}\right)^{2}+\left(\mathrm{v}_{\operatorname{ave} 2(\mathrm{mc})}-\mathrm{v}_{\operatorname{ave} 2(\mathrm{c})}^{ \pm}\right)^{2}+(\mathrm{v}\right.}$

Finally, the priority of each water pipeline for MRWs was determined by the following formula:

PipepriorityindexforMRWs $=\frac{\left.\mathrm{S}_{\mathrm{m}}^{-} \text {(byallstudiedcriteria }\right)^{-}}{\mathrm{S}_{\mathrm{m}}^{+}{ }_{\text {(byallstudiedcriteria) }}+\mathrm{S}_{\mathrm{m}}^{-}{ }_{\text {(byallstudiedcriteria })}}(6)$

This index is a number between zero and one, which the closer it is to the number 1, the higher the priority of the water pipeline for MRWs.

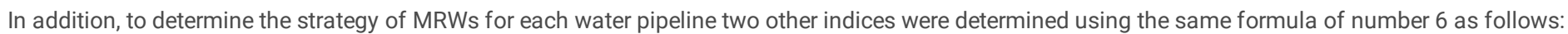

PFPindex $=\frac{\left.\mathrm{S}_{\mathrm{m}}^{-} \text {(bycriteriaeffectivein PipeFailureProbability }(P F P)\right)}{\mathrm{S}_{\mathrm{m}}^{+}{ }_{(\text {bycriteriaeffectiveinPFP })}+\mathrm{S}_{\mathrm{m}}^{-}{ }_{(\text {bycriteriaeffectiveinPFP })}}(7)$

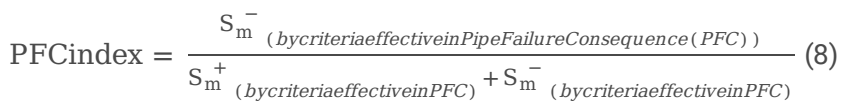

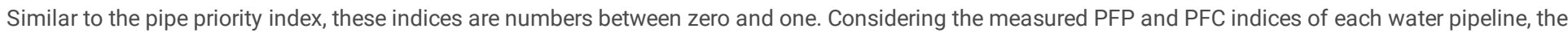
MRWs strategy of pipes were determined using the graph illustrated in Figure 4. This figure was obtained from the research of Salehi et al. (2020).

\section{Figure 4near here}

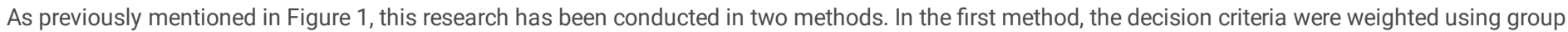

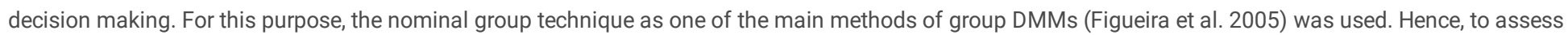

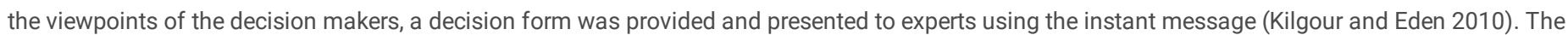

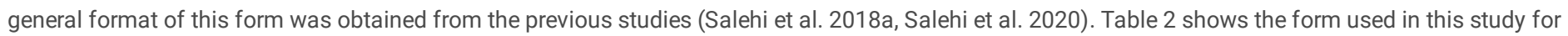

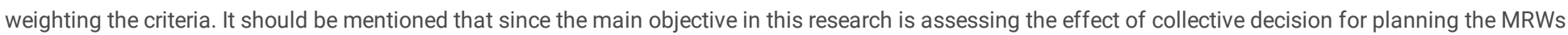
of the water pipelines, the weighting of experts is omitted for a correct judgment of the effect of expert viewpoints. 


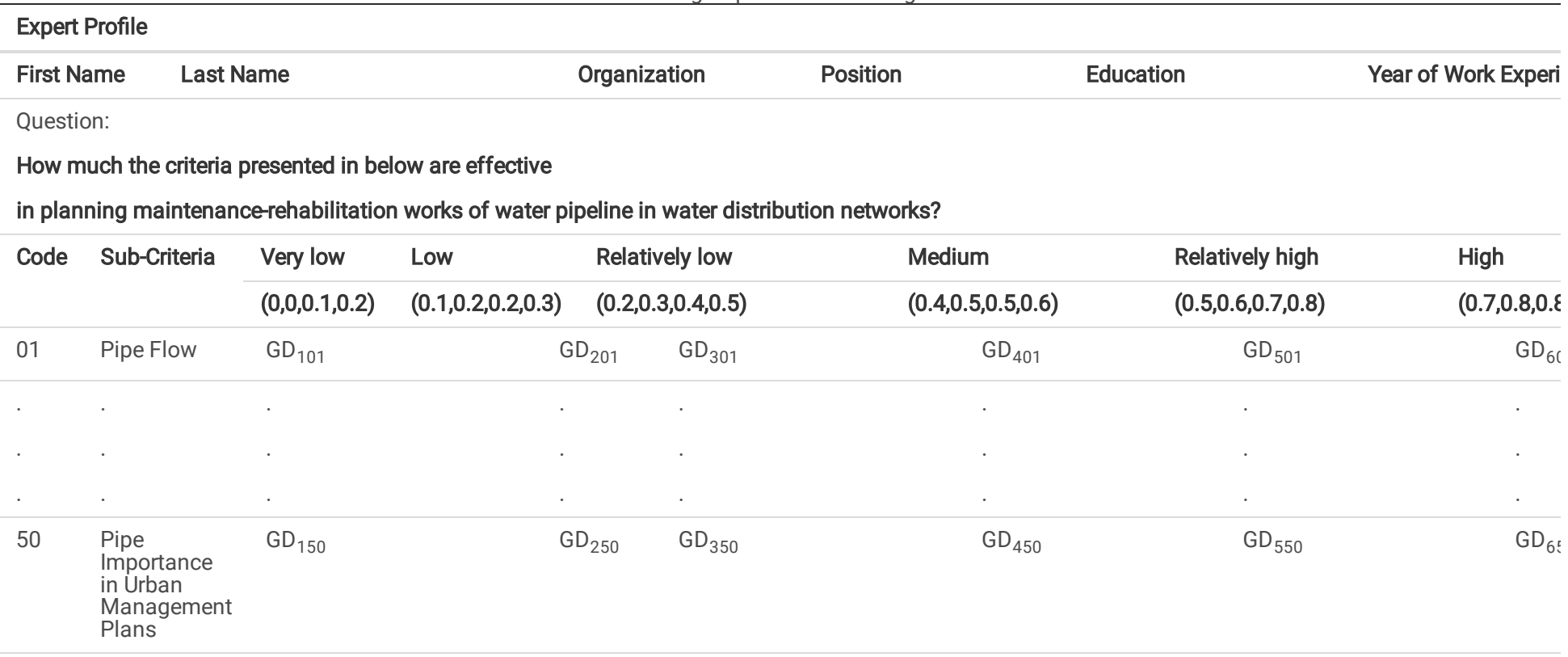

$\mathrm{GD}_{\text {ic }}$ : The $\mathrm{i}^{\text {th }}$ linguistic value assigned to $\mathrm{c}^{\text {th }}$ criterion by expert to determine the importance of $\mathrm{c}^{\text {th }}$ criterion

$\mathrm{i}=1$ (very low),2 (low),..., (very high), $\mathrm{c}=01,02, \ldots, 50$

As shown in Table 4, each of the linguistic values is related to a trapezoidal fuzzy number. Accordingly, the weight obtained for each criterion would be a fuzzy value. This value was achieved using the following formula:

$\tilde{\mathrm{w}}_{\mathrm{C}}=\left(w_{\min (\mathrm{c})}, w_{\text {ave1 (c) }}, w_{\text {ave2 (c) }}, w_{\max (c)}\right)$

$\tilde{w}_{C}=\backslash \operatorname{left}\left(\{\}_{-}\{\backslash \operatorname{text}\{k\}\}\{\}^{\wedge}\{\backslash \operatorname{text}\{m\} \backslash \operatorname{text}\{i\} \backslash \operatorname{text}\{n\}\} \backslash \operatorname{eft} \backslash\left\{\{w\}_{-}\{\backslash \operatorname{text}\{\min \} \backslash \operatorname{left}(\backslash \operatorname{text}\{c\} \backslash \operatorname{right})\} \backslash \operatorname{right} \backslash\right\}, \backslash\right.$ frac $\left\{\backslash \operatorname{sum} \_\{1\}^{\wedge}\{\backslash \operatorname{text}\{k\}\}\right.$

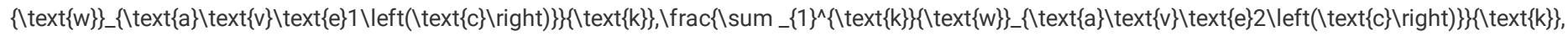

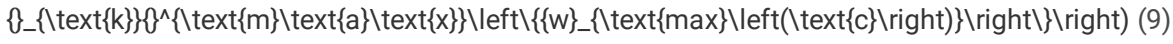

$\{\backslash \text { tilde }\{\backslash \text { text }\{w\}\}\}_{-}\{\backslash$ text $\{c\}\}$ : weight of $c^{\text {th }}$ criteria in the format of the fuzzy value; $c=01,02, \ldots, 50$

$\mathrm{k}=$ the numbers of decision-maker experts

Furthermore, after descaling the fuzzy values (first stage of Fuzzy TOPSIS model), the descaled fuzzy values were weighted using the formula as follows:

$\{\backslash \text { tilde }\{\backslash \operatorname{text}\{v\}\}\}_{-}\{\backslash \operatorname{text}\{m\} \backslash \operatorname{text}\{c\}\}^{\wedge}\{\}=\backslash \operatorname{left}\left(\backslash \operatorname{frac}\left\{\{\backslash \operatorname{text}\{x\}\}_{-}\{\backslash \operatorname{text}\{\min \} \backslash \operatorname{left}(\backslash \operatorname{text}\{\mathrm{m}\} \backslash \operatorname{text}\{c\} \backslash \operatorname{right})\}^{\wedge}\{\}\right\}\right.$

$\left\{\{\backslash \operatorname{text}\{x\}\}_{-}\left\{\{\backslash \operatorname{text}\{m\} \backslash \operatorname{text}\{a\} \backslash \operatorname{text}\{x\}\}^{\wedge}\left\{\{+\}_{-}\{\backslash \operatorname{left}(\backslash \operatorname{text}\{c\} \backslash \operatorname{right})\}\right\}\right\}\right\} .\{\mathrm{W}\}_{-}\{\backslash \operatorname{text}\{\min \} \backslash \operatorname{left}(\backslash \operatorname{text}\{c\} \backslash \operatorname{right})\}_{,} \backslash \operatorname{frac}\left\{\{\backslash \operatorname{text}\{x\}\}_{-}\{\backslash \operatorname{text}\{\operatorname{ave}\} 1 \backslash \operatorname{left}(\backslash \operatorname{text}\{\mathrm{m}\} \backslash \operatorname{text}\{c\} \backslash \operatorname{right})\}^{\wedge}\{\}\right\}$

$\left\{\{\backslash \operatorname{text}\{x\}\}_{-}\left\{\{\backslash \operatorname{text}\{m\} \backslash \operatorname{text}\{a\} \backslash \operatorname{text}\{x\}\}^{\wedge}\left\{\{+\}_{-}\{\backslash \operatorname{left}(\backslash \operatorname{text}\{c\} \backslash \operatorname{right})\}\right\}\right\}\right\}$.

$\{\mathrm{W}\}_{-}\{\backslash \operatorname{text}\{a\} \backslash \operatorname{text}\{\mathrm{v}\} \backslash \operatorname{text}\{\operatorname{e}\} 1 \backslash \operatorname{left}(\backslash \operatorname{text}\{c\} \backslash \operatorname{right})\}, \mid \operatorname{frac}\left\{\{\backslash \operatorname{text}\{\mathrm{x}\}\}_{-}\{\backslash \operatorname{text}\{\operatorname{ave}\} 2 \backslash \operatorname{left}(\backslash \operatorname{text}\{\mathrm{m}\} \backslash \operatorname{text}\{c\} \backslash \operatorname{right})\}^{\wedge}\{\}\right\}$

$\left\{\{\backslash \operatorname{text}\{x\}\}_{-}\left\{\{\backslash \operatorname{text}\{\operatorname{m}\rangle \backslash \operatorname{text}\{a\} \backslash \operatorname{text}\{x\}\}^{\wedge}\left\{\{+\}_{-}\{\backslash \operatorname{left}(\backslash \operatorname{text}\{c\} \backslash r i g h t)\}\right\}\right\}\right\}$.

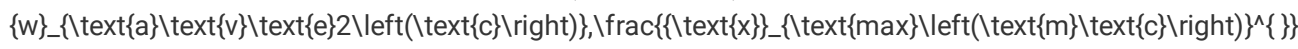

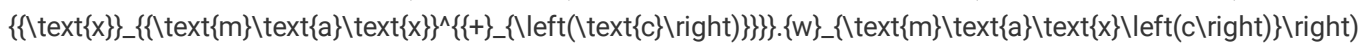

$\{\backslash \operatorname{text}\{x\}\}_{-}\left\{\{\backslash \operatorname{text}\{m\} \backslash \operatorname{text}\{a\} \backslash \operatorname{text}\{x\}\}^{\wedge}\left\{\{+\}_{-}\{\backslash \operatorname{left}(\backslash \operatorname{text}\{c\} \backslash \operatorname{right})\}\right\}\right\}=\{\}_{-}\{\backslash \operatorname{text}\{m\}\}\{\}^{\wedge}\{\backslash \operatorname{text}\{M\} \backslash \operatorname{text}\{a\} \backslash \operatorname{text}\{x\}\}\{\backslash \operatorname{text}\{x\}\}_{-}\{\backslash \operatorname{text}\{\max \} \backslash \operatorname{left}(\backslash \operatorname{text}\{m\} \backslash \operatorname{text}\{c\} \backslash \operatorname{right})\}^{\wedge}\{\}$

$\{\backslash \text { tilde }\{\backslash \text { text }\{v\}\}\}_{-}\{\backslash \text { text }\{m\} \backslash \text { text }\{c\}\}^{\wedge}\{\}$ : Weighted descaled fuzzy value of the $\mathrm{m}^{\text {th }}$ pipe in related to $\mathrm{c}^{\text {th }}$ criteria

$m=1,2, \ldots, m, c=01,02, \ldots, 50$

In the second method of this research, analytic steps of Fuzzy TOPSIS were performed without using group decision making. Finally, the results of two methods including group DMM and no-group DMM were compared.

\section{Results \& Discussion}

The results obtained from this research are presented in Figure 5 and Tables 5 and 6 . The discussion of these results is as follows:

Table 5: The similarity of the results of two methods to determine the pipe priorities 


\begin{tabular}{|c|c|c|c|c|c|c|c|c|c|c|c|c|c|c|c|}
\hline \multirow[t]{3}{*}{ State } & \multirow[t]{3}{*}{ City } & \multirow{3}{*}{$\begin{array}{l}\text { The Results of Two Methods and Their } \\
\text { Similarity }\end{array}$} & \multicolumn{13}{|c|}{ Pipe No. } \\
\hline & & & $\mathrm{P}_{1}$ & $\mathrm{P}_{2}$ & $P_{3}$ & $\mathrm{P}_{4}$ & $P_{5}$ & $P_{6}$ & $P_{7}$ & $P_{8}$ & $P_{9}$ & $P_{10}$ & $P_{11}$ & $P_{12}$ & $P_{13}$ \\
\hline & & & \multicolumn{13}{|c|}{ Pipe Priorities } \\
\hline \multirow[t]{3}{*}{ Ardabil } & \multirow[t]{3}{*}{ Ardabil } & Group DMM & 5 & 2 & 6 & 10 & 11 & 9 & 8 & 7 & 4 & 3 & 1 & & \\
\hline & & No-Group DMM & 5 & 2 & 6 & 10 & 11 & 8 & 9 & 7 & 4 & 3 & 1 & & \\
\hline & & Pipe Priority Similarity & $\sqrt{ }$ & $\sqrt{ }$ & $\sqrt{ }$ & $\sqrt{ }$ & $\sqrt{ }$ & प & प & $\sqrt{ }$ & $\sqrt{ }$ & $\sqrt{ }$ & $\sqrt{ }$ & & \\
\hline \multirow{2}{*}{$\begin{array}{l}\text { Chaharmahal } \\
\text { and }\end{array}$} & \multirow{3}{*}{$\begin{array}{l}\text { Shahr } \\
\text {-e- } \\
\text { Kord }\end{array}$} & Group DMM & 1 & 5 & 6 & 9 & 7 & 8 & 10 & 2 & 4 & 3 & & & \\
\hline & & No-Group DMM & 1 & 5 & 6 & 9 & 7 & 8 & 10 & 3 & 4 & 2 & & & \\
\hline Bakhtiari & & Pipe Priority Similarity & $\sqrt{ }$ & $\sqrt{ }$ & $\sqrt{ }$ & $\sqrt{ }$ & $\sqrt{ }$ & $\sqrt{ }$ & $\sqrt{ }$ & प & $\sqrt{ }$ & $\square$ & & & \\
\hline \multirow[t]{3}{*}{ Kurdistan } & \multirow[t]{3}{*}{ Marivan } & Group DMM & 1 & 3 & 5 & 2 & 4 & & & & & & & & \\
\hline & & No-Group DMM & 1 & 3 & 5 & 2 & 4 & & & & & & & & \\
\hline & & Pipe Priority Similarity & $\sqrt{ }$ & $\sqrt{ }$ & $\sqrt{ }$ & $\sqrt{ }$ & $\sqrt{ }$ & & & & & & & & \\
\hline \multirow{3}{*}{$\begin{array}{l}\text { Razavi } \\
\text { Khorasan }\end{array}$} & \multirow[t]{3}{*}{ Mashhad } & Group DMM & 9 & 11 & 12 & 13 & 6 & 8 & 1 & 10 & 5 & 7 & 4 & 2 & 3 \\
\hline & & No-Group DMM & 9 & 11 & 12 & 13 & 6 & 8 & 1 & 10 & 5 & 7 & 4 & 2 & 3 \\
\hline & & Pipe Priority Similarity & $\sqrt{ }$ & $\sqrt{ }$ & $\sqrt{ }$ & $\sqrt{ }$ & $\sqrt{ }$ & $\sqrt{ }$ & $\sqrt{ }$ & $\sqrt{ }$ & $\sqrt{ }$ & $\sqrt{ }$ & $\sqrt{ }$ & $\sqrt{ }$ & $\sqrt{ }$ \\
\hline \multirow{3}{*}{$\begin{array}{l}\text { Sistan } \\
\text { and } \\
\text { Baluchestan }\end{array}$} & \multirow[t]{3}{*}{ Sarbaz } & Group DMM & 9 & 6 & 5 & 4 & 2 & 10 & 8 & 3 & 7 & 1 & & & \\
\hline & & No-Group DMM & 9 & 7 & 5 & 4 & 2 & 6 & 10 & 3 & 8 & 1 & & & \\
\hline & & Pipe Priority Similarity & $\sqrt{ }$ & प & $\sqrt{ }$ & $\sqrt{ }$ & $\sqrt{ }$ & प & $\square$ & $\sqrt{ }$ & प & $\sqrt{ }$ & & & \\
\hline \multirow[t]{3}{*}{ South Khorasan } & \multirow[t]{3}{*}{ Ferdos } & Group DMM & 4 & 3 & 2 & 1 & 5 & & & & & & & & \\
\hline & & No-Group DMM & 4 & 1 & 2 & 3 & 5 & & & & & & & & \\
\hline & & Pipe Priority Similarity & $\sqrt{ }$ & प & $\sqrt{ }$ & प & $\sqrt{ }$ & & & & & & & & \\
\hline
\end{tabular}


Table 6

The similarity of the results of two methods to plan the Maintenance-Rehabilitation Works (MRV

\begin{tabular}{|c|c|c|c|c|c|c|c|c|c|c|}
\hline \multirow[t]{3}{*}{ State } & \multirow[t]{3}{*}{ City } & \multirow{3}{*}{$\begin{array}{l}\text { The } \\
\text { Results } \\
\text { of Two } \\
\text { Methods } \\
\text { and Their } \\
\text { Similarity }\end{array}$} & \multicolumn{8}{|l|}{ Pipe No. } \\
\hline & & & $P_{1}$ & $P_{2}$ & $P_{3}$ & $P_{4}$ & $P_{5}$ & $P_{6}$ & $P_{7}$ & $P_{8}$ \\
\hline & & & \multicolumn{8}{|c|}{ Pipes' MRWs Strategies } \\
\hline \multirow[t]{3}{*}{ Ardabil } & \multirow[t]{3}{*}{ Ardabil } & $\begin{array}{l}\text { Group } \\
\text { DMM }\end{array}$ & Monitor & $\begin{array}{l}\text { Assess } \\
\text { Proactively }\end{array}$ & Monitor & Monitor & $\begin{array}{l}\text { Repair on } \\
\text { Failure }\end{array}$ & Monitor & $\begin{array}{l}\text { Assess } \\
\text { Proactively }\end{array}$ & $\begin{array}{l}\text { Assess } \\
\text { Proactively }\end{array}$ \\
\hline & & $\begin{array}{l}\text { No-Group } \\
\text { DMM }\end{array}$ & $\begin{array}{l}\text { Assess } \\
\text { Proactively }\end{array}$ & $\begin{array}{l}\text { Assess } \\
\text { Proactively }\end{array}$ & $\begin{array}{l}\text { Assess } \\
\text { Proactively }\end{array}$ & $\begin{array}{l}\text { Assess } \\
\text { Proactively }\end{array}$ & $\begin{array}{l}\text { Assess } \\
\text { Proactively }\end{array}$ & $\begin{array}{l}\text { Assess } \\
\text { Proactively }\end{array}$ & $\begin{array}{l}\text { Assess } \\
\text { Proactively }\end{array}$ & $\begin{array}{l}\text { Assess } \\
\text { Proactively }\end{array}$ \\
\hline & & $\begin{array}{l}\text { Similarity } \\
\text { of MRWs } \\
\text { strategies }\end{array}$ & Q & $\sqrt{ }$ & ? & प & ? & ( & $\sqrt{ }$ & $\sqrt{ }$ \\
\hline \multirow{3}{*}{$\begin{array}{l}\text { Chaharmahal } \\
\text { and } \\
\text { Bakhtiari }\end{array}$} & \multirow{3}{*}{$\begin{array}{l}\text { Shahr } \\
\text {-e- } \\
\text { Kord }\end{array}$} & $\begin{array}{l}\text { Group } \\
\text { DMM }\end{array}$ & $\begin{array}{l}\text { Assess } \\
\text { Proactively }\end{array}$ & $\begin{array}{l}\text { Assess } \\
\text { Proactively }\end{array}$ & $\begin{array}{l}\text { Assess } \\
\text { Proactively }\end{array}$ & $\begin{array}{l}\text { Repair on } \\
\text { Failure }\end{array}$ & $\begin{array}{l}\text { Repair on } \\
\text { Failure }\end{array}$ & $\begin{array}{l}\text { Repair on } \\
\text { Failure }\end{array}$ & $\begin{array}{l}\text { Repair on } \\
\text { Failure }\end{array}$ & Monitor \\
\hline & & $\begin{array}{l}\text { No-Group } \\
\text { DMM }\end{array}$ & $\begin{array}{l}\text { Assess } \\
\text { Proactively }\end{array}$ & $\begin{array}{l}\text { Assess } \\
\text { Proactively }\end{array}$ & $\begin{array}{l}\text { Assess } \\
\text { Proactively }\end{array}$ & $\begin{array}{l}\text { Repair on } \\
\text { Failure }\end{array}$ & $\begin{array}{l}\text { Assess } \\
\text { Proactively }\end{array}$ & $\begin{array}{l}\text { Assess } \\
\text { Proactively }\end{array}$ & Monitor & $\begin{array}{l}\text { Assess } \\
\text { Proactively }\end{array}$ \\
\hline & & $\begin{array}{l}\text { Similarity } \\
\text { of MRWs } \\
\text { strategies }\end{array}$ & $\sqrt{ }$ & $\sqrt{ }$ & $\sqrt{ }$ & $\sqrt{ }$ & $\square$ & ૫ & ૫ & $\square$ \\
\hline \multirow[t]{3}{*}{ Kurdistan } & \multirow[t]{3}{*}{ Marivan } & $\begin{array}{l}\text { Group } \\
\text { DMM }\end{array}$ & $\begin{array}{l}\text { Assess } \\
\text { Proactively }\end{array}$ & Monitor & $\begin{array}{l}\text { Repair on } \\
\text { Failure }\end{array}$ & $\begin{array}{l}\text { Assess } \\
\text { Proactively }\end{array}$ & Monitor & & & \\
\hline & & $\begin{array}{l}\text { No-Group } \\
\text { DMM }\end{array}$ & $\begin{array}{l}\text { Assess } \\
\text { Proactively }\end{array}$ & $\begin{array}{l}\text { Assess } \\
\text { Proactively }\end{array}$ & $\begin{array}{l}\text { Assess } \\
\text { Proactively }\end{array}$ & $\begin{array}{l}\text { Assess } \\
\text { Proactively }\end{array}$ & $\begin{array}{l}\text { Assess } \\
\text { Proactively }\end{array}$ & & & \\
\hline & & $\begin{array}{l}\text { Similarity } \\
\text { of MRWs } \\
\text { strategies }\end{array}$ & $\sqrt{ }$ & ૫ & ? & $\sqrt{ }$ & ૫ & & & \\
\hline \multirow[t]{3}{*}{$\begin{array}{l}\text { Razavi } \\
\text { Khorasan }\end{array}$} & \multirow[t]{3}{*}{ Mashhad } & $\begin{array}{l}\text { Group } \\
\text { DMM }\end{array}$ & $\begin{array}{l}\text { Repair on } \\
\text { Failure }\end{array}$ & $\begin{array}{l}\text { Repair on } \\
\text { Failure }\end{array}$ & $\begin{array}{l}\text { Repair on } \\
\text { Failure }\end{array}$ & $\begin{array}{l}\text { Repair on } \\
\text { Failure }\end{array}$ & $\begin{array}{l}\text { Repair on } \\
\text { Failure }\end{array}$ & $\begin{array}{l}\text { Repair on } \\
\text { Failure }\end{array}$ & $\begin{array}{l}\text { Assess } \\
\text { Proactively }\end{array}$ & $\begin{array}{l}\text { Repair on } \\
\text { Failure }\end{array}$ \\
\hline & & $\begin{array}{l}\text { No-Group } \\
\text { DMM }\end{array}$ & $\begin{array}{l}\text { Assess } \\
\text { Proactively }\end{array}$ & Monitor & $\begin{array}{l}\text { Repair on } \\
\text { Failure }\end{array}$ & $\begin{array}{l}\text { Repair on } \\
\text { Failure }\end{array}$ & $\begin{array}{l}\text { Assess } \\
\text { Proactively }\end{array}$ & $\begin{array}{l}\text { Assess } \\
\text { Proactively }\end{array}$ & $\begin{array}{l}\text { Assess } \\
\text { Proactively }\end{array}$ & Monitor \\
\hline & & $\begin{array}{l}\text { Similarity } \\
\text { of MRWs } \\
\text { strategies }\end{array}$ & ૫ & ( & $\sqrt{ }$ & $\sqrt{ }$ & ૫ & ૧ & $\sqrt{ }$ & $\square$ \\
\hline \multirow{3}{*}{$\begin{array}{l}\text { Sistan } \\
\text { and } \\
\text { Baluchestan }\end{array}$} & \multirow[t]{3}{*}{ Sarbaz } & $\begin{array}{l}\text { Group } \\
\text { DMM }\end{array}$ & Monitor & $\begin{array}{l}\text { Assess } \\
\text { Proactively }\end{array}$ & $\begin{array}{l}\text { Repair on } \\
\text { Failure }\end{array}$ & $\begin{array}{l}\text { Assess } \\
\text { Proactively }\end{array}$ & $\begin{array}{l}\text { Assess } \\
\text { Proactively }\end{array}$ & $\begin{array}{l}\text { Repair on } \\
\text { Failure }\end{array}$ & $\begin{array}{l}\text { Assess } \\
\text { Proactively }\end{array}$ & $\begin{array}{l}\text { Assess } \\
\text { Proactively }\end{array}$ \\
\hline & & $\begin{array}{l}\text { No-Group } \\
\text { DMM }\end{array}$ & $\begin{array}{l}\text { Assess } \\
\text { Proactively }\end{array}$ & $\begin{array}{l}\text { Assess } \\
\text { Proactively }\end{array}$ & $\begin{array}{l}\text { Repair on } \\
\text { Failure }\end{array}$ & $\begin{array}{l}\text { Assess } \\
\text { Proactively }\end{array}$ & $\begin{array}{l}\text { Assess } \\
\text { Proactively }\end{array}$ & $\begin{array}{l}\text { Repair on } \\
\text { Failure }\end{array}$ & $\begin{array}{l}\text { Assess } \\
\text { Proactively }\end{array}$ & $\begin{array}{l}\text { Assess } \\
\text { Proactively }\end{array}$ \\
\hline & & $\begin{array}{l}\text { Similarity } \\
\text { of MRWs } \\
\text { strategies }\end{array}$ & प & $\sqrt{ }$ & $\sqrt{ }$ & $\sqrt{ }$ & $\sqrt{ }$ & $\sqrt{ }$ & $\sqrt{ }$ & $\sqrt{ }$ \\
\hline \multirow[t]{3}{*}{$\begin{array}{l}\text { South } \\
\text { Khorasan }\end{array}$} & \multirow[t]{3}{*}{ Ferdos } & $\begin{array}{l}\text { Group } \\
\text { DMM }\end{array}$ & Monitor & $\begin{array}{l}\text { Assess } \\
\text { Proactively }\end{array}$ & $\begin{array}{l}\text { Assess } \\
\text { Proactively }\end{array}$ & $\begin{array}{l}\text { Assess } \\
\text { Proactively }\end{array}$ & Monitor & & & \\
\hline & & $\begin{array}{l}\text { No-Group } \\
\text { DMM }\end{array}$ & $\begin{array}{l}\text { Assess } \\
\text { Proactively }\end{array}$ & $\begin{array}{l}\text { Assess } \\
\text { Proactively }\end{array}$ & $\begin{array}{l}\text { Assess } \\
\text { Proactively }\end{array}$ & $\begin{array}{l}\text { Assess } \\
\text { Proactively }\end{array}$ & $\begin{array}{l}\text { Assess } \\
\text { Proactively }\end{array}$ & & & \\
\hline & & $\begin{array}{l}\text { Similarity } \\
\text { of MRWs } \\
\text { strategies }\end{array}$ & ૫ & $\sqrt{ }$ & $\sqrt{ }$ & $\sqrt{ }$ & ૫ & & & \\
\hline
\end{tabular}

1. As illustrated obviously in Figure 5, in the determination of the pipe priorities, the similarity of the results of two methods (group DMM and no-group DMM) is significantly further in comparison to the results of MRWs strategies of the pipes. Accordingly, the similarity of pipe priorities in the two methods is more than $80 \%$ in the four water companies; whereas, for results of MRWs strategies, in only one case this similarity is more than $80 \%$. It means that the effectiveness of collective decisions to prioritize the pipes is not very significant. While determining the pipe renovation strategies, the group DMM could be effective. Furthermore, this is approved that based on viewpoints of network operators in these water companies, it seems that the MRWs strategies obtained from group DMM are more realistic and decisive in comparison to the results of no-group DMM;

2. As shown in Table 5, it is clear that the weights resulting from group decision making do not have a significant effect on changing the priority of pipes. Hence, in the cities of Ferdos (South Khorasan province), Shahr-e-Kord (Chaharmahal and Bakhtiari province) and Ardabil (Ardabil province) only the priorities of the two pipes have been moved; and relocating the priority of pipes in Sarbaz city (Sistan and Baluchestan province) has occurred in pipes with low priority. While, as illustrated in Table 6, using collective decisions led the renovation strategies of pipes to be more accurate in most water companies studied in this research (Ardabil, Chaharmahal and Bakhtiari, Kurdistan, Razavi Khorasan and South Khorasan). 
3. As represented in Figure 5, the results of the two methods in determining the MRWs strategies of pipes is more than $60 \%$ in 3 water companies (Sarbaz, Ferdos and Shahr-e-Kord). While, compared to other cities (Ardabil, Marivan and Mashhad), this similarity for pipe priorities is less in these water companies. On the other hand, as shown in Figure 3, the criteria studied in water companies of Sarbaz and Shahr-e-Kord is less than other companies. Therefore, considering Figures 3 and 5, it seems that reducing the number of criteria studied can almost lead to the reversal of the results. Accordingly, regarding to the viewpoints of network operators and the results presented in previous paragraphs, it can be generally said that reducing the number of decision criteria can have an adverse effect on the accuracy of the results of group decisions.

4. The least similarity of the results is related to the MRWs strategy of the pipes in Mashhad and Marivan. It means that the most effective group decision on determining the strategy of pipe renovation is related to the water companies of these two cities. However, the number of pipes in these two cities was significantly different. Hence, the number of pipes studied in Mashhad was equal to 13 , whereas, in Marivan was equal to 5 . This result indicates that the number of pipes does not affect the obtained results. Thus, the model developed in this study can be robust, and provides accurate results with any number of pipes.

5. As represented in Figure 3, it is clear that the most number of decision makers are related to water companies of Khorasan Razavi (Mashhad), Chaharmahal and Bakhtiari (Shahr-e-Kord), and Sistan and Baluchestan (Sarbaz). However, considering the results presented in Figure 5, it is obvious that the viewpoints of decision makers are significantly different in these companies. In addition, the results of Ardabil are very close to Shahr-e-Kord and, the results of Mashhad are close to Marivan. While, the number of decision makers in Ardabil province was 9, and for Chaharmahal and Bakhtiari province (Shahr-e-Kord), the 14 experts were volunteers. There is also a significant difference between the number of decision makers in Khorasan Razavi (Mashhad) and Kurdistan (Marivan) provinces. Hence, 23 decision makers participated in the Water Company of Khorasan Razavi, whereas, 9 experts were proposed in Kurdistan Province for this research. Accordingly, it can be concluded that increasing the number of decision makers does not necessarily make the results to be better or worse; and the viewpoints of decision makers are more important than their number.

6. Considering Table 1 and Figure 5, It seems that for planning the MRWs of pipes, increasing the level of education degree in decision makers (Ardabil and Khorasan Razavi provinces) as well as work experience in them (Ardabil and Kurdistan provinces) can be effective in improving the results of collective decisions. However, only increasing work experience (Khorasan Razavi Province), could not necessarily lead to better results for group decisions in renovation planning of water pipelines.

7. Based on results obtained from this research, it can be stated that using a qualitative risk-based method could be useful in fields with deep uncertainty as well as hesitation in group decisions such as collective decisions for planning the water pipelines' MRWs.

\section{Conclusion}

Maintenance-Rehabilitation Works (MRWs) is one of the most important activities in water companies. In particular, in the case of water pipelines of Water Distribution Networks (WDNs), the planning of these works should be coherent, efficient, and cost-effective. Therefore, considering the complexities of operation and maintenance in WDNs, using collective decisions is inevitable in this field. However, group decision-making for planning MRWs of the water pipelines does not necessarily lead to effective programs. Indeed, it is essential firstly to assess the effectiveness of group decisions in pipes renovation planning. This important subject was considered in this research. Hence, to assess the effectiveness of collective decisions in water companies of Iran, six provinces were selected; and the viewpoints of 76 experts in these companies were investigated for planning MRWs of the water pipelines. To assess the hesitant viewpoints of experts as well as imprecise data of WDNs, a qualitative risk-based group decision model was developed in this research. The results revealed that using this model could be useful for planning MRWs of the water pipelines. However, it was found that group decisions do not have a decisive effect on pipes prioritization, but could be decisive for determining the MRWs strategies of the water pipelines. Furthermore, it was shown that increasing the decision criteria could make the results more realistic; nevertheless, the numbers of pipes analysed and the numbers of experts who participated, do not have a direct effect on results; While, their viewpoints could be very effective in renovation planning of the pipes. It must be mentioned that this research has been conducted in selected water companies of Iran, and the results might be changed in another country, even in other water companies of Iran. However, it seems that the results obtained from this research could be inspired for future studies in the field of group decisions for maintenance-rehabilitation planning of the water pipeline.

\section{Abbreviations}

DMM: Decision-Making Method

MRW: Maintenance-Rehabilitation Work

PFP: Pipe Failure Probability

PFC: Pipe Failure Consequence

RC-WDSR: Risk Component-based Water Distribution System Renewal

TOPSIS: Technique for Order Preferences by Similarity to an Ideal Solution

WDN: Water Distribution Network

\section{Declarations}

\section{Funding}


Not applicable.

\section{Conflicts of interest/Competing interests}

Not applicable.

\section{Availability of data and material}

Not applicable.

\section{Code availability}

Not applicable.

\section{Authors' contributions}

It is acknowledged that all following authors have been contributed to accomplish this research and writing this paper, respectively:

Sattar Salehi, Kaveh Nezam Khiavi, Mohammadreza Danesh, Mortez Mehrdad, Hamid Shalpooshe, Esmat Azariunf, Reza Khalajig, Hossein Khalilianh, Abbas Shafighii

\section{Ethics approval}

Not applicable.

\section{Consent to participate}

Not applicable.

\section{Consent for publication}

Not applicable.

\section{References}

1. Alvisi S, Franchini M (2006) Near-optimal rehabilitation scheduling of water distribution systems based on a multi-objective genetic algorithm. Civil Engineering and Environmental Systems 23(3):143-160

2. Alvisi S, Franchini M (2009) Multiobjective optimization of rehabilitation and leakage detection scheduling in water distribution systems. J Water Resour Plan Manag 135(6):426-439

3. Amorocho-Daza H, Cabrales S, Santos R, Saldarriaga J (2019) A new multi-Criteria decision analysis methodology for the selection of new water supply infrastructure. Water 11(4):805

4. Anisseh M, Yusuff M, R.b (2011) Developing a fuzzy TOPSIS model in multiple attribute group decision making. Scientific Research and Essays 6(5):1046-1052

5. Barton NA, Farewell TS, Hallett SH, Acland TF (2019) Improving pipe failure predictions: Factors affecting pipe failure in drinking water networks. Water Res 164:114926

6. Bicik J (2010) A risk-based decision support system for failure management in water distribution networks. University of Exeter

7. Cabral M, Loureiro D, Covas D (2019) Using economic asset valuation to meet rehabilitation priority needs in the water sector.Urban Water Journal,1-10

8. Carneiro J, Alves P, Marreiros G, Novais P (2019) A conceptual group decision support system for current times: dispersed group decision-making. Springer, pp 150-159

9. Carneiro J, Alves P, Marreiros G, Novais P (2021) Group decision support systems for current times: Overcoming the challenges of dispersed group decision-making. Neurocomputing 423:735-746

10. Carrico N, Covas D, Almeida MC, Leitão J, Alegre H (2012) Prioritization of rehabilitation interventions for urban water assets using multiple criteria decision-aid methods. Water Sci Technol 66(5):1007-1014

11. Choi T, Han J, Koo J (2015) Decision method for rehabilitation priority of water distribution system using ELECTRE method. Desalination Water Treat 53(9):2369-2377

12. Christodoulou S, Deligianni A, Aslani P, Agathokleous A (2009) Risk-based asset management of water piping networks using neurofuzzy systems Comput Environ Urban Syst 33(2):138-149

13. D'Ercole M, Righetti M, Raspati GS, Bertola P, Ugarelli M, R (2018) Rehabilitation Planning of Water Distribution Network through a Reliability-Based Risk Assessment. Water 10(3):277

14. da Silva Monte MB, Morais DC, de Almeida-Filho AT (2016) Analysis of the decision-makers' weights on preventive maintenance in a water supply system, pp. 001092-001097, IEEE

15. Dell'Aira F, Cancelliere A, Creaco E, Pezzinga G (2021) Novel Comprehensive Approach for Phasing Design and Rehabilitation of Water Distribution Networks. J Water Resour Plan Manag 147(3):04021001 
16. Devera JC (2013) Risk assessment model for pipe rehabilitation and replacement in a water distribution system. California Polytechnic State University, San Luis Obispo

17. Elshaboury N, Attia T, Marzouk M (2020a) Application of evolutionary optimization algorithms for rehabilitation of water distribution networks. J Constr Eng Manag 146(7):04020069

18. Elshaboury N, Attia T, Marzouk M (2020b) Comparison of several aggregation techniques for deriving analytic network process weights. Water Resour Manage 34(15):4901-4919

19. Fletcher SM, Miotti M, Swaminathan J, Klemun MM, Strzepek K, Siddiqi A (2017) Water Supply Infrastructure Planning: Decision-Making Framework to Classify Multiple Uncertainties and Evaluate Flexible Design. J Water Resour Plan Manag 143(10):04017061

20. Figueira J, Greco S, Ehrgott M (2005) Multiple criteria decision analysis: state of the art surveys. Springer

21. Fontana ME, Morais DC (2016) Decision model to control water losses in distribution networks. Production 26(4):688-697

22. Fontana ME, Morais DC (2017) Water distribution network segmentation based on group multi-criteria decision approach.Production27

23. Giustolisi O, Laucelli D, Savict DA (2006) Development of rehabilitation plans for water mains replacement considering risk and cost-benefit assessment. Civil Engineering and Environmental Systems 23(3):175-190

24. GÜL Ş, FIRAT M, DETERMINATION OF PRIORITY REGIONS FOR REHABILITATION IN WATER NETWORKS BY MULTIPLE CRITERIA DECISION MAKING METHODS (2020). Sigma: Journal of Engineering \& Natural Sciences/Mühendislik ve Fen Bilimleri Dergisi 38(3)

25. Haidar H, Le Gauffre P (2004) Multi-criteria model for annual rehabilitation planning of water supply networks:. sensitivity analysis and impacts of the quantity of data

26. Haider H, Sadiq R, Tesfamariam S (2015) Selecting performance indicators for small and medium sized water utilities: Multi-criteria analysis using ELECTRE method. Urban Water Journal 12(4):305-327

27. Hsieh C-J, Fifić M, Yang C-T (2020) A new measure of group decision-making efficiency. Cognitive research: principles and implications 5(1):1-23

28. Hwang C-L, Yoon K (1981) Multiple attribute decision making: a state of the art survey. Lecture Notes in Economics and Mathematical Systems 186

29. Islam MS, Sadiq R, Rodriguez MJ, Najjaran H, Francisque A, Hoorfar M (2013) Evaluating water quality failure potential in water distribution systems: a fuzzy-TOPSIS-OWA-based methodology. Water Resour Manage 27(7):2195-2216

30. Jiang J, Chen Y-w, Chen Y-w, Yang K-w (2011) TOPSIS with fuzzy belief structure for group belief multiple criteria decision making. Expert Syst Appl 38(8):9400-9406

31. Kapelan Z, Savic D, Walters G (2004) Optimal Rehabilitation of Water Distribution Systems Under Uncertain Demands. World Scientific, p 24

32. Khameneh PA, Lavasani SM, Nodehi RN, Arjmandi R (2019) Water distribution network failure analysis under uncertainty. International Journal of Environmental Science and Technology,1-12

33. Kilgour DM, Eden C (2010) Handbook of group decision and negotiation. Springer Science \& Business Media

34. Lee EJ, Criddle CS, Geza M, Cath TY, Freyberg DL (2018) Decision support toolkit for integrated analysis and design of reclaimed water infrastructure. Water Res 134:234-252

35. Lee YW, Bogardi I, Kim JH (2000) Decision of water supply line under uncertainty. Water Res 34(13):3371-3379

36. Lin P, Yuan X-X (2019) A two-time-scale point process model of water main breaks for infrastructure asset management. Water Res 150:296-309

37. Lindhe A, Rosén L, Norberg T, Bergstedt O (2009) Fault tree analysis for integrated and probabilistic risk analysis of drinking water systems. Water Res 43(6):1641-1653

38. Madani K, Read L, Shalikarian L (2014) Voting under uncertainty: a stochastic framework for analyzing group decision making problems. Water Resour Manage 28(7):1839-1856

39. Marques J, Cunha M (2020) Upgrading water distribution networks to work under uncertain conditions. Water Supply

40. Minaei A, Haghighi A, Ghafouri HR (2019) Computer-Aided Decision-Making Model for Multiphase Upgrading of Aged Water Distribution Mains. J Water Resour Plan Manag 145(5):04019008

41. Minatour Y, Bonakdari H, Zarghami M, Bakhshi MA (2015) Water supply management using an extended group fuzzy decision-making method: a case study in north-eastern Iran. Applied Water Science 5(3):291-304

42. Morais DC, Almeida AT (2010) Water network rehabilitation: a group decision-making approach. Water SA 36(4):0-0

43. Morais DC, de Almeida AT (2007) Group decision-making for leakage management strategy of water network. Resour Conserv Recycl 52(2):441-459

44. Morais DC, de Almeida AT, Figueira JR (2014) A sorting model for group decision making: a case study of water losses in Brazil. Group Decis Negot 23(5):937-960

45. Mutikanga HE, Sharma SK, Vairavamoorthy K (2011) Multi-criteria decision analysis: a strategic planning tool for water loss management. Water Resour Manage 25(14):3947-3969

46. Noori A, Bonakdari H, Salimi AH, Gharabaghi B (2020) A Group Multi-Criteria Decision-Making Method for Water Supply Choice Optimization. SocioEconomic Planning Sciences, p 101006

47. Phan HC, Dhar AS, Hu G, Sadiq R (2019) Managing Water Main Breaks in Distribution Networks-A Risk-Based Decision Making. Reliability Engineering \& System Safety, p 106581

48. Rahmani F, Behzadian K, Ardeshir A (2015) Rehabilitation of a water distribution system using sequential multiobjective optimization models. J Water Resour Plan Manag 142(5):C4015003 
49. Ramos C, Muñuzuri J, Aparicio-Ruiz P, Onieva L (2021) A decision support system to design water supply and sewer pipes replacement intervention programs. Reliability Engineering \& System Safety, p 107967

50. RazaviToosi SL, Samani J (2019) A Fuzzy Group Decision Making Framework Based on ISM-FANP-FTOPSIS for Evaluating Watershed Management Strategies. Water Resour Manage 33(15):5169-5190

51. Rogers JW, Louis GE (2008) Risk and opportunity in upgrading the US drinking water infrastructure system. J Environ Manage 87(1):26-36

52. Roozbahani A, Zahraie B, Tabesh M (2012) PROMETHEE with precedence order in the criteria (PPOC) as a new group decision making aid: an application in urban water supply management. Water Resour Manage 26(12):3581-3599

53. Sadiq R, Saint-Martin E, Kleiner Y (2008) Predicting risk of water quality failures in distribution networks under uncertainties using fault-tree analysis. Urban Water Journal 5(4):287-304

54. Saldarriaga J, Ochoa S, Moreno M, Romero N, Cortés O (2010) Prioritised rehabilitation of water distribution networks using dissipated power concept to reduce non-revenue water. Urban Water Journal 7(2):121-140

55. Salehi S, Jalili Ghazizadeh M, Tabesh M (2018a) A comprehensive criteria-based multi-attribute decision-making model for rehabilitation of water distribution systems. Struct Infrastruct Eng 14(6):743-765

56. Salehi S, Jalili Ghazizadeh M, Tabesh M, Valadi S, Nia S, S.P (2020) A risk component-based model to determine pipes renewal strategies in water distribution networks.Structure and Infrastructure Engineering,1-22

57. Salehi S, Tabesh M, Jalili Ghazizadeh M (2018b) HRDM Method for Rehabilitation of Pipes in Water Distribution Networks with Inaccurate OperationalFailure Data. J Water Resour Plan Manag 144(9):04018053

58. Salehi S, Tabesh M, Jalili Ghazizadeh M (2019) Development of a Prioritization Model for Rehabilitation of Pipes in Water Distribution Systems with Minimum Structural Data. Water and wastewater journal 29(6):40-55

59. Salman A, Moselhi O, Zayed T (2013) Scheduling Model for Rehabilitation of Distribution Networks Using MINLP. J Constr Eng Manag 139(5):498-509

60. Scheidegger A, Scholten L, Maurer M, Reichert P (2013) Extension of pipe failure models to consider the absence of data from replaced pipes. Water Res 47(11):3696-3705

61. Scholten L, Scheidegger A, Reichert P, Mauer M, Lienert J (2014) Strategic rehabilitation planning of piped water networks using multi-criteria decision analysis. Water Res 49:124-143

62. Shortridge JE, Guikema SD (2014) Public health and pipe breaks in water distribution systems: Analysis with internet search volume as a proxy. Water Res $53: 26-34$

63. Tabesh M, Saber H (2012) A prioritization model for rehabilitation of water distribution networks using GIS. Water Resour Manage 26(1):225-241

64. Tabesh M, Roozbahani A, Roghani B, Salehi S, Faghihi NR, Heydarzadeh R (2020) Prioritization of non-revenue water reduction scenarios using a riskbased group decision-making approach. Stoch Env Res Risk Assess 34(11):1713-1724

65. Tang J, Meng F, Cabrerizo FJ, Herrera-Viedma E (2019) A procedure for group decision making with interval-valued intuitionistic linguistic fuzzy preference relations. Fuzzy Optim Decis Making 18(4):493-527

66. Torres JM, Brumbelow K, Guikema SD (2009) Risk classification and uncertainty propagation for virtual water distribution systems. Reliab Eng Syst Saf 94(8):1259-1273

67. Trojan F, Morais DC (2012) Prioritising alternatives for maintenance of water distribution networks: A group decision approach. Water SA 38(4):555-564

68. Tscheikner-Gratl F, Egger P, Rauch W, Kleidorfer M (2017) Comparison of multi-criteria decision support methods for integrated rehabilitation prioritization. Water 9(2):68

69. Tscheikner-Gratl F, Sitzenfrei R, Rauch W, Kleidorfer M (2016) Integrated rehabilitation planning of urban infrastructure systems using a street section priority model. Urban Water Journal 13(1):28-40

70. Urich C, Rauch W (2014) Exploring critical pathways for urban water management to identify robust strategies under deep uncertainties. Water Res 66:374-389

71. Vahdani B, Mousavi SM, Tavakkoli-Moghaddam R (2011) Group decision making based on novel fuzzy modified TOPSIS method. Appl Math Model 35(9):4257-4269

72. Vieira J, Cabral M, Almeida N, Silva JG, Covas D (2020) Novel methodology for efficiency-based long-term investment planning in water infrastructures. Struct Infrastruct Eng 16(12):1654-1668

73. Wang F, Zheng X-z, Li N, Shen X (2019) Systemic vulnerability assessment of urban water distribution networks considering failure scenario uncertainty. Int J Crit Infrastruct Prot 26:100299

74. Wéber R, Huzsvár T, Hős C (2020) Vulnerability analysis of water distribution networks to accidental pipe burst. Water Res $184: 116178$

75. Willuweit L, O'Sullivan JJ (2013) A decision support tool for sustainable planning of urban water systems: Presenting the Dynamic Urban Water Simulation Model. Water Res 47(20):7206-7220

76. Wu W, Xu Z, Kou G (2020) Evaluation of group decision making based on group preferences under a multi-criteria environment. Technological and Economic Development of Economy 26(6):1187-1212

77. Wu Z, Abdul-Nour G (2020) Comparison of multi-criteria group decision-making methods for urban sewer network plan selection. CivilEng 1(1):26-48

78. Xie YL, Xia DH, Huang GH, Li W, Xu Y (2017) A multistage stochastic robust optimization model with fuzzy probability distribution for water supply management under uncertainty. Stoch Env Res Risk Assess 31(1):125-143

79. Yazdani M, Alidoosti A, Basiri MH (2012) Risk analysis for critical infrastructures using fuzzy TOPSIS.Journal of Management Research4(1) 
80. Zhou X, Tang Z, Xu W, Meng F, Chu X, Xin K, Fu G (2019) Deep learning identifies accurate burst locations in water distribution networks. Water Res 166:115058

81. Zolghadr-Asli B, Bozorg-Haddad O, Enayati M, Chu X (2021) A review of 20-year applications of multi-attribute decision-making in environmental and water resources planning and management. Environment, Development and Sustainability, pp 1-26

\section{Figures}

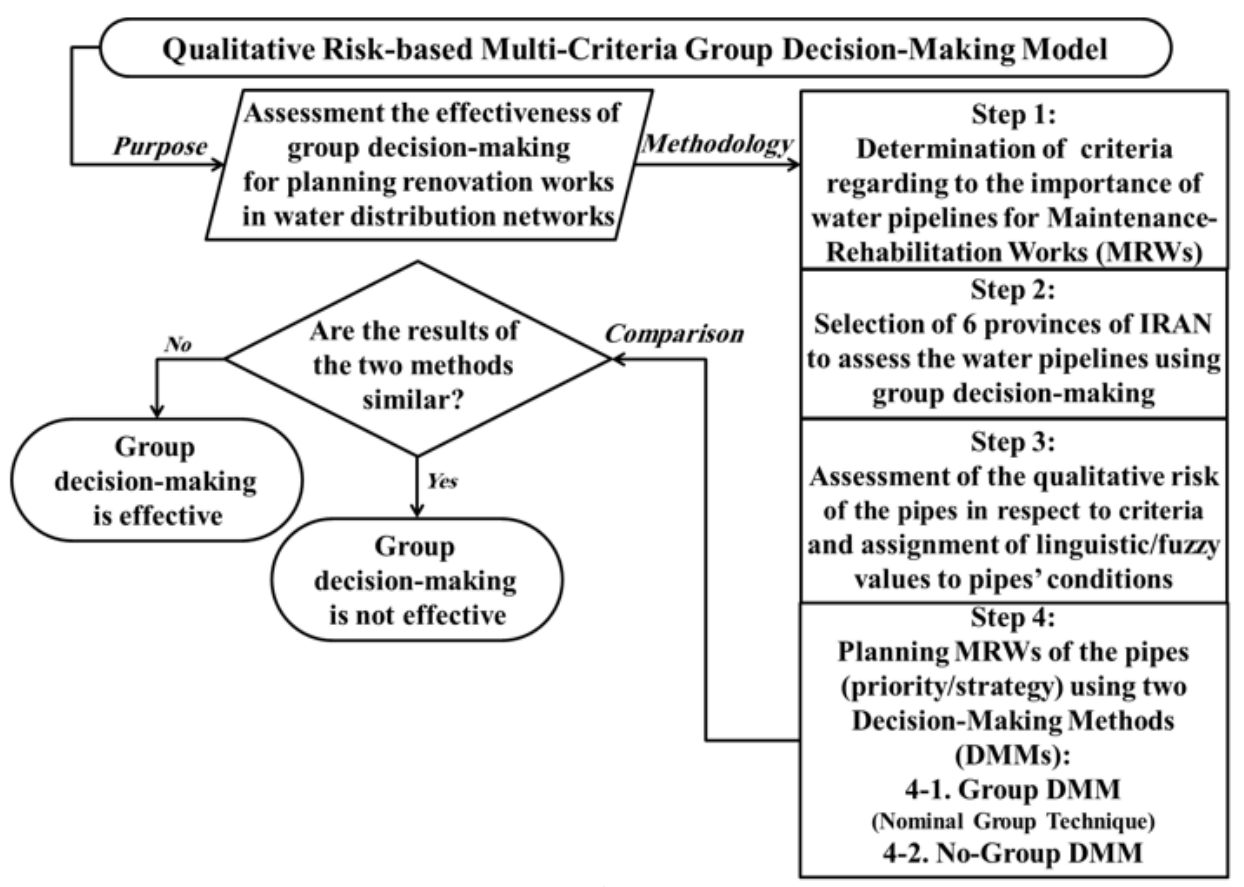

Figure 1

The analytic steps of model developed in this research 


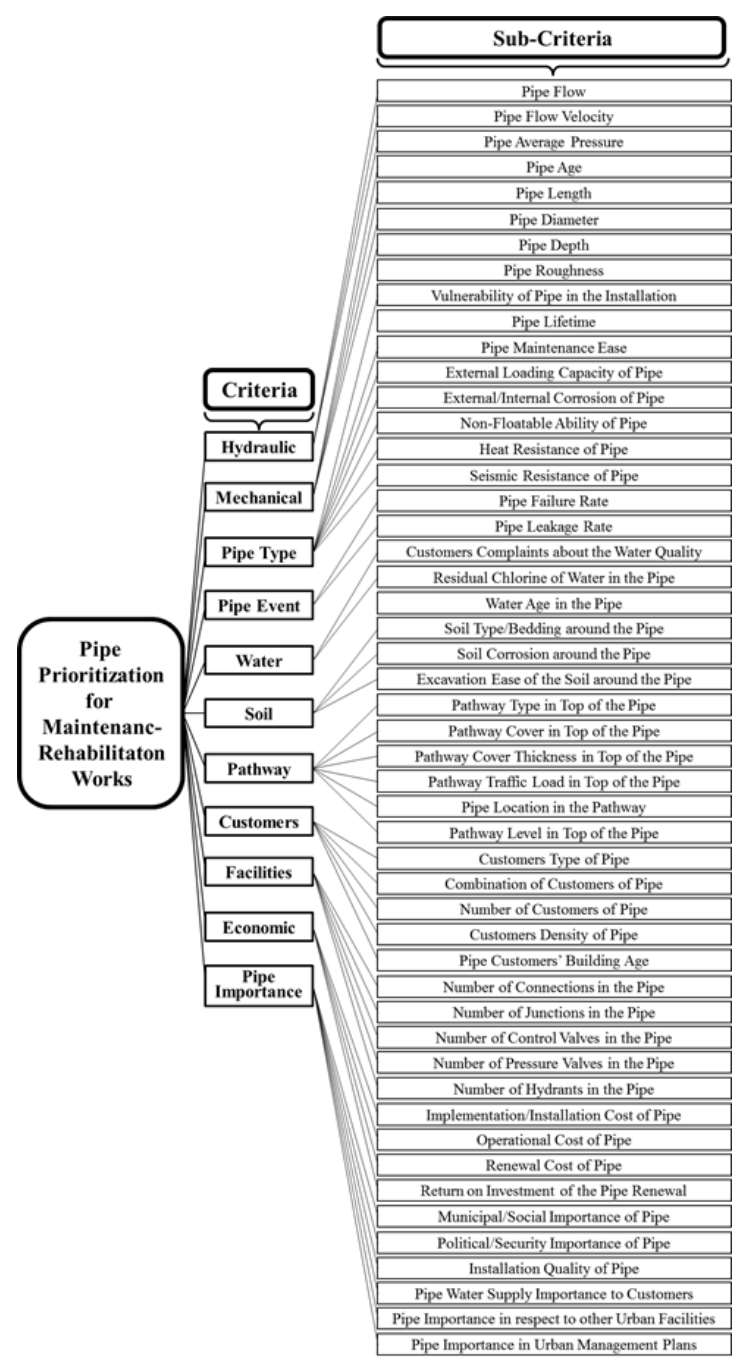

Figure 2

The criteria and sub-criteria considered in this research

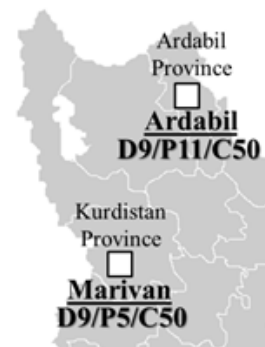

Razai Khorasan Province

Mashhad

D23/P13/C50

D9/P5/C50

South Khorasan

Province

Chaharmahal and Bakhtiari

Province

Shahr-e-Kord

Ferdos

D10/P5/C50

D14/P10/C43

The City Studied in each Province

D: Number of Decision Maker in Water Company

P: Number of Pipes Proposed by Water Company

C: Number of Criteria Assessed in Water Company

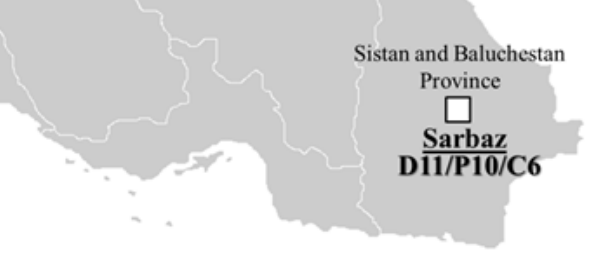

Figure 3

Page 16/17 
The number of decision makers/pipes/criteria in water companies studied in this research

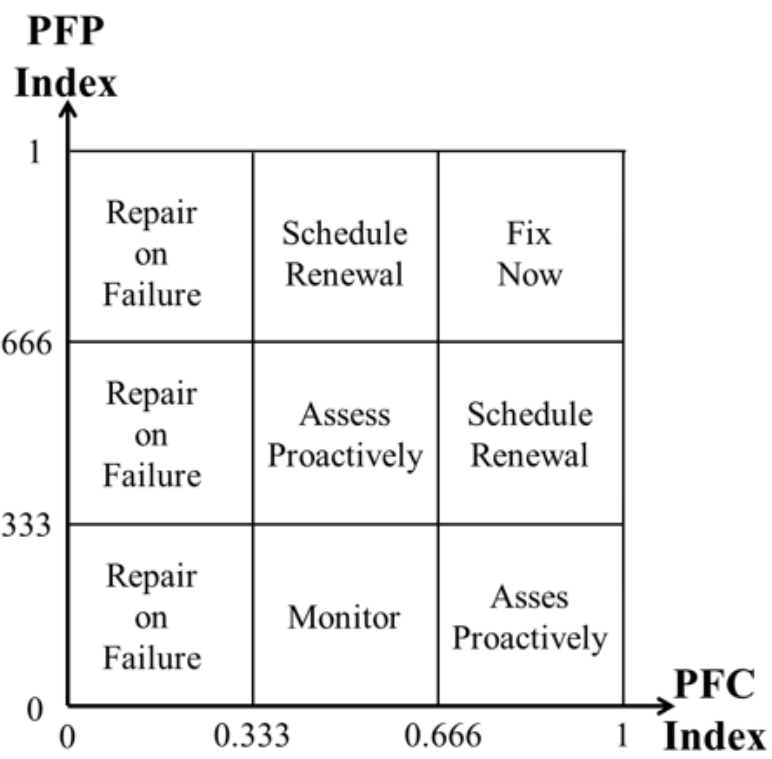

Figure 4

Determination of the MRWs strategy of pipes using PFP and PFC indices (Salehi et al. (2020))

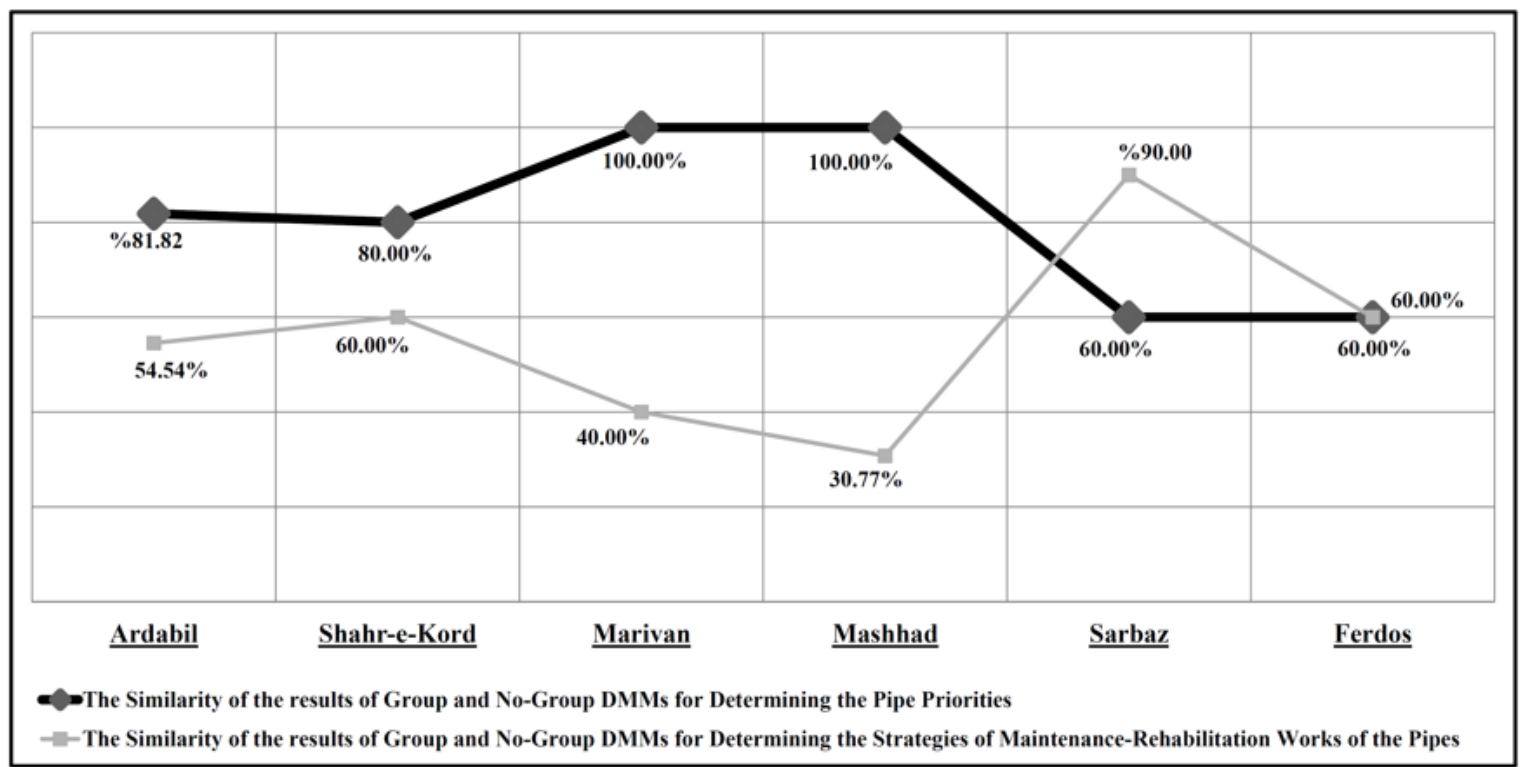

Figure 5

The similarity of the results of Group and No-Group DMMs 